\title{
STUDI KUANTITATIF: BIAYA TRANSAKSI DALAM PERSPEKTIF MANAJEMEN PEMERINTAHAN DI INDONESIA
}

\author{
Arie Purnomo \\ Dosen Universitas Muhammadiyah Sorong
}

\begin{abstract}
The research aim to know the transaction cost in government management prospective consist of the government cost and market cost with suitable the government service in government management prospective.

The result of government in applied of transaction cost have affect by the government cost suitable with routine cost, development cost, human resource cost and facility cost suitable with information, administration, operational and technology costs in applied the suitable of service with principle, accountable, leadership, productivity and service quality. The appointment of market cost have positive toward transaction cost for several activity or job program in government scope.

The government instance have responsibility in appointment of transaction cost with give of propose planning suitable with need of government in applied of information, administration, operational and technology cost which affected toward suitable of service. Although the transaction cost in specific occured with the transaction cost particularly relate with cost transaction because the government cost require to suitable with transaction cost.
\end{abstract}

\section{PENDAHULUAN}

Permasalahan yang sering ditemukan berkaitan dengan aktivitas administrasi yang diterapkan oleh pemerintah, khususnya yang berkaitan dengan pelayanan adalah permasalahan biaya transaksi (cost transaction) yang tidak sesuai dengan peningkatan biaya menurut kepentingan pemerintah, kepentingan pasar dalam mempengaruhi biaya transaksi dan kesesuaian pelayanan. Ini menjadi polemik dalam aktivitas pelayanan pemerintah dewasa ini yang sering menjadi sorotan dan keluhan dari publik tentang pelayanan yang diberikan, yang searah dengan adanya tuntutan reformasi birokrasi dalam pemerintahan.

Mewujudkan pemerintahan yang baik dibutuhkan kepastian hukum dan kemauan yang baik (goodwill) dari pemerintah untuk melakukan tata kelola administrasi dan keuangan yang sesuai dengan kesesuaian pelayanan dalam melakukan biaya transaksi atas biaya pemerintah (government cost) dan biaya pasar (market cost). Pemerintah sebagai organisasi non profit dalam memberikan pelayanan tidak mencerminkan sebagai organisasi yang mengutamakan kepentingan pelayanan. Pemerintah dalam memberikan pelayanan selalu berpatokan pada biaya pasar dalam 
menetapkan biaya transaksi dalam membebani kesesuaian pelayanan pemerintah. Pesch (2005:177) menetapkan biaya transaksi selalu mempertimbangkan biaya pemerintah dan biaya pasar dalam menentukan kesesuaian layanan yang diberikan. Teulings (2003:67) menyatakan penetapan biaya transaksi tidak terlepas dari adanya kepentingan pemerintah untuk mengelola biaya yang efektif dalam mengambil sebuah keputusan mengenai kegiatan layanan yang diterapkan.

$\begin{array}{ccr}\text { Biaya } & \text { transaksi } & \text { selalu } \\ \text { diperhadapkan } & \text { pada } & \text { adanya }\end{array}$ permasalahan yang berkaitan dengan biaya pemerintah yang dikeluarkan dan biaya pasar yang harus disesuaikan dengan kebutuhan pelayanan. Waarden (2006:120) menyatakan biaya transaksi dipengaruhi oleh besarnya biaya pemerintah dan penetapan penyesuaian biaya pasar. Klein (2000:90) menyatakan kinerja suatu organsisasi dalam memberikan pelayanan dilihat dari biaya transaksi yang dikenakan. Biaya transaksi yang berimbang adalah terpenuhinya kesesuaian antara biaya layanan dan manfaat kepentingan yang diperoleh (Damascus, 2004:36).

Kenyataan yang ditemukan dewasa ini pada kebanyakan organisasi pemerintah yang ada di Indonesia berbasis layanan, selalu menetapkan biaya transaksi yang tidak sesuai dengan biaya permintaan pemerintah dan tidak sesuai dengan biaya pasar, dalam mempengaruhi kesesuaian pelayanan. Ruiter (2008:15) menyatakan biaya transaksi merupakan asumsi perilaku manusia dalam menetapkan suatu biaya yang rasional dan menguntungkan. Asumsi perilaku menetapkan berdasarkan asumsi keinginan antara layanan dan kepentingan. Williamson (1996:165) menyatakan biaya transaksi merupakan perwujudan layanan dan kepentingan pencapaian tujuan organisasi.

Menetapkan biaya transaksi yang dilakukan oleh pemerintah dipengaruhi oleh besarnya biaya pengeluaran pemerintah dan penyesaian biaya pasar. Williamson (1996:170) menyatakan biaya transaksi yang diterapkan mengacu pada pertimbangan biaya pemerintah berupa biaya rutin, biaya pembangunan, biaya kebutuhan SDM dan biaya untuk penyediaan sarana prasarana. Black (2007:89) menyatakan biaya transaksi yang diterapkan selalu menyesuaikan biaya pasar sesuai dengan pembiayaan biaya negosiasi, biaya monitoring, biaya pertukaran dan biaya evaluasi.

Antara biaya pemerintah dan biaya penyesuaian pasar sangat menentukan penetapan biaya transaksi yang dilakukan oleh pemerintah dalam mempengaruhi penyesuaian layanan yang diberikan. Fenomena ini terjadi dalam menentukan biaya transaksi. Pada prinsipnya instansi pemerintah dalam menjalankan tugas pokok dan fungsinya mengacu kepada Peraturan yang berlaku. Hal yang berkaitan dengan biaya transaksi dalam pelaksanaan uraian kerja yaitu berkaitan dengan biaya transaksi aset, biaya program dan biaya kegiatan yang dilakukan dalam melayani unit kerja instansi pemerintah yang ada dalam naungan Sekretariat Daerah.

Wujud dari biaya pemerintah yang sering menimbulkan permasalahan berkaitan dengan biaya transaksi yaitu biaya rutin yang tidak sesuai dengan pengalokasiannya, biaya pembangunan yang tidak sesuai dengan peruntukan, biaya untuk kebutuhan SDM tidak sesuai dengan pemanfaatan dan biaya penyediaan sarana prasarana tidak sesuai dengan 
ketersediaan fasilitas kerja. Stephen (2005:90) menyatakan biaya pemerintah dialokasikan sesuai dengan usulan kebutuhan dan prioritas.

Hambatan dalam menentukan besarnya biaya pemerintah, tergantung dari kebutuhan alokasi biaya rutin, biaya pembangunan, biaya kebutuhan SDM dan biaya penyediaan sarana dan prasarana. Alokasi permintaan usulan anggaran dari masing-masing unit organisasi mempengaruhi biaya transaksi yang berkaitan dengan penyesuaian wujud layanan yang diterapkan. Ruiter (2008:149) menyatakan biaya pemerintah mempengaruhi biaya transaksi tergantung pada besarnya alokasi anggaran yang diprioritaskan sesuai peruntukannya.

Besarnya biaya pemerintah yang diusulkan, mempengaruhi biaya transaksi dari setiap pos-pos pengalokasian pembiayaan berupa biaya transaksi informasi, administrasi, operasional dan teknologi. Penambahan biaya transaksi sering tidak bersesuaian antara wujud layanan yang diberikan dengan terpenuhinya kepentingan dari suatu proses pelayanan yang diharapkan. Ruiter (2008:153) menyatakan biaya transaksi diperlukan untuk kelancaran layanan dan terenuhinya kepentingan yang diharapkan dari sebuah proses layanan birokrasi.

Instansi pemerintahdalam melakukan penetapan biaya transaksi selalu mempertimbangkan kondisi biaya pasar. Biaya pasar merupakan sebuah penetapan biaya yang didasarkan pada mekanisme pasar dalam menentukan produk dan jasa yang menjadi obyek transaksi. Steenge (2008:171) menyatakan bahwa biaya pasar merupakan biaya bentukan dari mekanisme pasar yang mempengaruhi penetapan biaya transaksi produk dan jasa.

Aspek yang menentukan biaya pasar dalam mempengaruhi biaya transaksi ditentukan oleh aspek negosiasi, monitoring, pertukaran dan evaluasi, yang memiliki pos-pos biaya dalam proses penetapannya. Biaya negosiasi biasanya ditentukan oleh pelaksana yang berkepentingan dalam menetapkan biaya yang berlaku, biaya monitoring terjadi dari pelaporan yang ditemukan, biaya pertukaran dilakukan berdasarkan aspek perbaikan dan penggantian produk barang dan jasa, serta biaya evaluasi dikeluarkan berdasarkan hasil penilaian dari program dan kegiatan yang dilakukan.

$$
\text { Kenyataan ini sering }
$$

ditemukan dalam penetapan biaya transaksi yang dilakukan khususnya dalam penetapan biaya usulan suatu program atau kegiatan yang mengeluarkan biaya transaksi dalam mensosialisasikan anggaran yang dikeluarkan. Sosialisasi anggaran yang keluar selalu mempertimbangkan biaya pasar yang sesuai dengan mekanisme pasar dalam menetapkan biaya negosiasi, monitoring, pertukaran dan evaluasi.

Terjadinya sebuah kesenjangan dalam mempertanyakan biaya transaksi yang ditetapkan, yang penetapannya tidak dilakukan secara profesional dalam mempertimbangkan besarnya biaya pemerintah dan biaya pasar dalam mempengaruhi suatu kegiatan birokrasi dan pelayanan. Besarnya biaya transaksi cenderung berdampak ketidaksesuaian pelayanan berdasarkan prinsip layanan, akuntabilitas layanan, kepemimpinan layanan, produktivitas dan kualitas pelayanan.

Peningkatan biaya transaksi ditentukan oleh besarnya biaya informasi, administrasi, operasional dan penggunaan teknologi dalam 
melakukan kegiatan pelayanan. Karenanya diperlukan adanya sebuah standar penetapan biaya yang disesuaikan dengan kegiatan layanan yang efisien dan efektif. Kondisi Instansi pemerintahdalam mengelola biaya informasi, administrasi, operasional dan teknologi cenderung tidak dibarengi dengan kesesuaian layanan.

Kesesuaian pelayanan akan terwujud jika biaya transaksi dilakukan secara proporsional berdasarkan layanan dan kepentingan pemerintah dalam mendorong terwujudnya prinsip pelayanan yang tepat, akuntabilitas layanan yang dapat dipercaya, kepemimpinan layanan yang berorientasi tujuan, produktivitas berorientasi hasil dan kualitas layanan yang memuaskan.

Apa yang telah diuraikan di atas, ini menjadi spesifik bagi penelitian yang peneliti lakukan, khususnya untuk melihat bagaimana pentingnya penetapan biaya pemerintah sebagai konstruk variabel eksogen X1 dan penetapan biaya pasar sebagai konstruk variabel eksogen X2 untuk melihat adanya pengaruh dan dimensional dengan biaya transaksi sebagai variabel konstruk endogen $\mathrm{Y}$ dan kesesuaian pelayanan sebagai variabel konstruk endogen $Z$, yang membedakan dengan penelitian terdahulu Maria Lambetta van Genugten (2008) yang meneliti tentang ekonomi biaya transaksi dan pelayanan publik sebagai sebuah asumsi perilaku dalam memperhatikan kegiatan transaksi sebagai sebuah unit analisis, penilaian institusi alternatif mengenai penetapan biaya transaksi pada sektor publik yang dapat dilihat secara empiris dan teoritis dalam kenyataannya pada berbagai pelayanan publik di tingkat lokal.

Hal yang sama juga dilakukan Silberd Hart (2007) yang menunjukkan bahwa penelitian ini menyingkap instrumen tinjauan administrasi publik dan kajian ekonomi regional dalam suatu birokrasi, mampu mengungkapkan penganalisaan biaya pemerintah sesuai dengan mata rantai biaya transaksi, pengeluaran berdasarkan opportunistic behavior dalam transaksi pelayanan. William Harrison (2008) pada intinya meneliti biaya transaksi yang ditetapkan oleh pemerintah untuk memenuhi pelayanan publik sebagai solusi dalam menemukan biaya pelayanan yang dikeluarkan dari sebuah penetapan perencanaan anggaran yang ditetapkan oleh pemerintah sesuai dengan pengalokasiannya. Dan Corazon Jessy (2008) merekomendasikan bahwa alokasi pembiayaan dan penetapan anggaran biaya pemerintah kepada publik sangat ditentukan oleh biaya transaksi dan kepercayaan pelayanan dari perilaku peluang dalam menerapkan biaya yang pantas kepada publik.

Keempat penelitian tersebut memberikan sebuah rekomendasi yang sama dalam melihat pentingnya biaya transaksi dalam suatu kegiatan pelayanan, namun yang spesifik dari penelitian yang peneliti lakukan dalam membedakan dengan penelitian yang lain bahwa peneliti melakukan sebuah model konstruksi di dalam melihat pentingnya penetapan biaya pemerintah dan biaya pasar untuk menentukan besarnya pengaruh terhadap kegiatan biaya transaksi dan kesesuaian pelayanan yang diterapkan oleh pemerintah dalam hal ini instansi pemerintah di Indonesia.

Uraian di atas menunjukkan bahwa biaya transaksi dipengaruhi 
oleh biaya yang dibutuhkan pemerintah untuk melaksanakan tugas pokok dan fungsi, dan dipengaruhi biaya pasar dalam menetapkan besarnya keperluan penetapan barang dan jasa. Melalui biaya transaksi yang tepat akan berpengaruh terhadap terwujudnya kesesuaian pelayanan organisasi. Berdasarkan hal tersebut, peneliti tertarik memilih judul: Biaya Transaksi dalam Prospektif Manajemen pemerintahan (Studi Kuantitatif atas Layanan Instansi Pemerintahan di Indonesia).

Berdasarkan pernyataan masalah tersebut, maka dirumuskan masalah yang akan diteliti sebagai berikut: 1) apakah penetapan biaya pemerintah memberikan pengaruh terhadap biaya transaksi atas kesesuaian pelayanan? 2) apakah penetapan biaya pasar memberikan pengaruh terhadap biaya transaksi atas kesesuaian pelayanan? 3) apakah penetapan biaya transaksi memberikan pengaruh terhadap kesesuaian pelayanan? dan 4) apakah penetapan biaya pemerintah, biaya pasar dan biaya transaksi memberikan pengaruh terhadap kesesuaian pelayanan? 


\section{METODOLOGI}

Pendekatan yang digunakan dalam penelitian ini adalah penelitian kuantitatif yaitu penelitian yang memerlukan penjelasan analisis yang dapat diuji dengan menggunakan metode statistik. Menurut Sugiyono (2005:55) penelitian kuantitatif adalah penelitian untuk melihat pengaruh antara variabel bebas terhadap variabel terikat, atau variabel bebas terhadap variabel antara dan variabel terikat.

Populasi dan sampel penelitian ini adalah masyarakat yang mendapatkan pelayanan dalam kurun waktu 1 tahun (November 2010 Oktober 2011) sebanyak 2.158 orang. Sampel berdasarkan rumus Slovin sebanyak 337 responden.

Analisis data yang digunakan yaitu teknik statistik Structural Equation Model (SEM). Dengan pemodelan melalui SEM dan program Analysis of Moment Structures (AMOS 4.01) ini dimungkinkan mampu menjawab pertanyaan yang bersifat regresif maupun dimensional.

\section{HASIL DAN PEMBAHASAN}

Data kegiatan dan penganggaran yang telah direncanakan, disesuaikan berdasarkan biaya transaksi dilihat dari biaya pemerintah terdiri atas biaya rutin, biaya pembangunan, biaya kebutuhan SDM dan biaya penyediaan sarana prasarana, biaya pasar yang terdiri atas biaya negosiasi, biaya monitoring, biaya pertukaran dan biaya evaluasi, dengan mempertimbangkan besarnya biaya transaksi yang dilakukan berdasarkan pertimbangan biaya informasi, biaya administrasi, biaya operasional dan biaya teknologi dalam mewujudkan kesesuaian pelayanan berdasarkan prinsip, akuntabilitas pelayanan, kepemimpinan pelayanan, produktivitas pelayanan dan kualitas pelayanan.

Berdasarkan model SEM yang sudah fit, maka dilakukan uji signifikansi hubungan antar variabel. Pengujian dilakukan secara parsial dengan cara membandingkan nilai critical ratio $(\mathrm{CR})$ atau probability $(\mathrm{p})$ pada nilai regression weights. Nilai critical ratio $(\mathrm{CR})$ sama dengan nilai critical student (t-value) pada model regresi biasa (non struktural). Model lengkap yang dapat menjelaskan hubungan kausal yang terjalin di antara variabel biaya pemerintah dan biaya pasar terhadap biaya transaksi dan kesesuaian pelayanan yang merupakan hasil pengembangan dari model-model tunggal dari setiap faktor yang telah diuji sebelumnya.

Dengan menggunakan bantuan perangkat lunak Amos 4.01 diperoleh hasil perhitungan goodness-of-fit indices (GFI) atas model lengkap di atas yang menggambarkan jalinan sinergis antar masing-masing variabel penelitian serta indikator yang telah valid menjadi pengukurnya masingmasing. Gambaran secara lebih lengkapnya disajikan pada Tabel 5.17 berikut. 


\begin{tabular}{|c|c|c|c|c|}
\hline Kriteria & Nilai Cut-off & $\begin{array}{l}\text { Tahap } \\
\text { Awal } \\
\end{array}$ & $\begin{array}{l}\text { Tahap } \\
\text { Akhir }\end{array}$ & $\begin{array}{l}\text { 1-3eterangan17 } \\
\text { Model Akhir }\end{array}$ \\
\hline Chi-Square & Diharapkan kecil & 1129.041 & 192.455 & Baik \\
\hline $\begin{array}{l}\text { Probabilitas } \\
\text { Signifikansi }\end{array}$ & $<0.05$ & 0.000 & 0.000 & Signifikan \\
\hline Cmindf & $\leq 3.00$ & 11.180 & 4.582 & Kurang Baik \\
\hline GFI & $\geq 0.90$ & 0.975 & 0.983 & Sangat Baik \\
\hline AGFI & $\geq 0.90$ & 0.935 & 0.942 & Sangat Baik \\
\hline TLI & $\geq 0.94$ & 0.503 & 0.862 & Baik \\
\hline CFI & $\geq 0.95$ & 0.708 & 0.957 & Sangat Baik \\
\hline RMSEA & $\leq 0.08$ & 0.175 & 0.103 & Kurang Baik \\
\hline \multicolumn{2}{|c|}{$\begin{array}{c}\text { Contoh Hasil Komputasi Kriteria } \\
\text { Goodness-of-Fit Indices (GFI) } \\
\text { Model Lengkap Tahap Awal dan } \\
\text { Akhir }\end{array}$} & \multicolumn{3}{|c|}{$\begin{array}{l}=\alpha_{0}+\alpha_{1} Y_{1}+\alpha_{2} X_{1}+ \\
=-6.846+3.356 x_{1}+\end{array}$} \\
\hline
\end{tabular}

Hasil perbandingan antara hasil perhitungan antara tahap awal dengan tahap akhir dengan kriteria goodness of fit suatu model sebagaimana nampak pada tabel di atas menunjukkan kesesuaian yang baik. Oleh karena itu, dapat diambil

suatu keputusan bahwa model tahap akhir yang menggambarkan hubungan kausal antar masing-masing variabel yang diuji dapat diterima dan digunakan untuk keperluan selanjutnya.

Berdasarkan tabel di atas, maka dapat dibuat persamaanpersamaan regresi sebagai berikut :

Fungsi dan persamaan Biaya Transaksi (Y)

$$
\begin{array}{r}
\mathrm{Y}=\mathrm{f}\left(\mathrm{X}_{1,} \mathrm{X}_{2}\right) \\
\quad=\beta_{0}+\beta_{1} \mathrm{X}_{1}+\beta_{2} \mathrm{X}_{2}+
\end{array}
$$

$\mu_{1}$

$3.493 \mathrm{x}_{2}$

$$
=-3.356+3.531 x_{1}+
$$

Fungsi dan persamaan Kesesuaian Pelayanan (Z)

$$
\mathrm{Z}=\mathrm{f}\left(\mathrm{Y}, \mathrm{X}_{1}, \mathrm{X}_{2}\right)
$$

Pada tabel dan persamaan di atas terlihat bahwa dari berbagai hubungan kausal yang terjadi antar variabel, tampaknya semua memiliki hubungan kausal yang positif dan signifikan, karena memiliki nilai probabilitas $(\mathrm{P}) \leq 0,05$ dan $\mathrm{CR}(\mathrm{t}$-value) $\geq 1,96$. Secara lengkap hasil pengujian antar variabel dalam penelitian ini dapat diuraikan sebagai berikut: 1) biaya pemerintah berpengaruh signifikan terhadap biaya transaksi; 2) biaya pasar berpengaruh signifikan terhadap biaya transaksi; 3) biaya pemerintah berpengaruh signifikan terhadap kesesuaian pelayanan; 4) biaya pasar berpengaruh signifikan terhadap kesesuaian pelayanan; dan 5) biaya transaksi berpengaruh signifikan terhadap kesesuaian pelayanan pemerintah.

\section{Kesimpulan}

Berdasarkan hasil penelitian dan pembahasan, disimpulkan sebagai berikut: 1) instansi pemerintahdalam penerapan biaya transaksi sangat dipengaruhi oleh penetapan biaya pemerintah sesuai tingkat kebutuhan biaya rutin, biaya pembangunan, biaya kebutuhan SDM dan biaya penyediaan 
sarana prasarana, dalam kenyataannya untuk memberikan kesesuaian pelayanan Biro Keuangan dan Kekayaan menetapkan biaya transaksi sesuai pembiayaan informasi, administrasi, operasional dan teknologi, dalam rangka meringankan beban pembiayaan untuk melaksakan kesesuaian pelayanan sesuai prinsip, akuntabilitas, kepemimpinan, produktivitas dan kualitas pelayanan; 2) penetapan biaya pasar berpengaruh positif terhadap biaya transaksi atas kesesuaian pelayanan dari berbagai aktivitas atau program kerja dari masing-masing unit pemerintah yang ada pada lingkup Biro Keuangan dan Kekayaan Daerah. Penetapan biaya pasar yang terdiri dari biaya negosiasi, biaya monitoring, biaya pertukaran dan biaya evaluasi dibiayai oleh pemerintah daerah dalam penetapannya telah disesuaikan dengan biaya transaksi atas kesesuaian pelayanan yang ada pada Kantor Sekretariat Daerah; 3) instansi pemerintahyang memiliki tanggungjawab dalam penetapan biaya transaksi, telah memberikan perencanaan usulan sesuai dengan kebutuhan masing-masing unit pemerintah untuk menetapkan biaya informasi, biaya administrasi, biaya operasional dan biaya teknologi yang berpengaruh terhadap kesesuaian pelayanan. Adanya biaya transaksi yang pengenaan biayanya sering terjadi tarik menarik dalam penetapan biaya transaksi khususnya yang berkaitan dengan penggunaan biaya transaksi untuk biaya informasi, administrasi, operasional dan penggunaan teknologi, karenanya biaya pemerintah perlu disesuaikan dengan tingkat penyesuaian biaya transaksi; dan 4) kesesuaian prinsip pelayanan yang dihasilkan dari penerapan biaya transaksi berupa terwujudnya pelayanan yang sesuai prinsip, akuntabilitas, kepemimpinan, produktivitas dan kualitas pelayanan. Secara keselurhan terlihat bahwa dari berbagai hubungan kausal yang terjadi antar variabel, tampaknya semua memiliki hubungan kausal yang positif dan signifikan, karena memiliki nilai probabilitas $(\mathrm{P}) \leq 0,05$ dan $\mathrm{CR}(\mathrm{t}$-value $)$ $\geq 1,96$.

\section{Saran}

$\begin{array}{cr}\text { Berdasarkan } & \text { hasil } \\ \text { pembahasandalam penelitian ini }\end{array}$ dikemukakan beberapa saran yang dapat dipertimbangkan oleh pihak Instansi pemerintahsebagai berikut: 1) kepala Instansi pemerintahdalam penerapan biaya transaksi perlu melakukan perencanan yang matang dalam mengalokasikan biaya pemerintah yang terdiri atas tingkat kebutuhan biaya rutin, biaya pembangunan, biaya kebutuhan SDM dan biaya penyediaan sarana prasarana, agar aparat dapat memberikan kesesuaian pelayanan baik dalam menetapkan biaya transaksi sesuai pembiayaan informasi, administrasi, operasional dan teknologi, dalam rangka meringankan beban pembiayaan untuk melaksakan kesesuaian pelayanan sesuai prinsip, akuntabilitas, kepemimpinan, produktivitas dan kualitas pelayanan; 2) dalam hal penetapan biaya pasar lingkup Biro Keuangan dan Kekayaan Daerah, harus mampu melakukan negosiasi, monitoring, pertukaran dan evaluasi dalam penetapannya telah disesuaikan dengan biaya transaksi atas kesesuaian pelayanan yang ada pada Kantor Sekretariat Daerah; 3) perlu meningkatkan tanggungjwab 
dalam penetapan biaya berupa usulan untuk menetapkan biaya informasi, biaya administrasi, biaya operasional dan biaya teknologi yang berpengaruh terhadap kesesuaian pelayanan; dan 4) perlu peningkatan dalam penyesuaian pelayanan dari penerapan biaya transaksi berupa terwujudnya pelayanan yang sesuai prinsip, akuntabilitas, kepemimpinan, produktivitas dan kualitas pelayanan.

\section{DAFTAR PUSTAKA}

Black, Shafritz, 2007. Classics of Public Administration, USA: Harcourt Brace \& Company.

Gibson, Kendall, 1996. The Process of Network Administration. New York: Simon and Schuster.

Hellriegel, Henault, 1998. Managing of Organization. New York, NY: Prentice Hall.

Helmert, Marcel, 2008. Service Autonomy in Concept and Theory. Published by American Press, USA.

Hens,John \& Gitto, E.A. Russell, 2008. Government management, Mc Grow-Hill, inc., Singapura.

Herlind, Harold, 2008. Power and Society of Public Administration. Singapore: Singapore Press Holding.

Hermanto, 2008. Pengantar Analisis Kebijakan Publik. (Penyunting: Darwin Muhadjir). Yogyakarta: Gajah Mada University Press.
Jackson, J.H, Morgan,CP, dan Paolillo,J, 1978. Organization Theory, A Macro Perspective for management, Prentice-Hall, New York.

James, Perchy, 2008. Implementation of Service Administration Public. London: Sage.

Jeffrey, Malic, 2008. How to Managed of Organization Effectiveness. New Jersey, Prentice Hall.

Jingrat, Korten, 2007. Strategic Public Administration. Public Managers Forum.

Joan, Macraully, 2008. Organization Theory in Public Administration. New York, John Wiley and Sons.

Joseph, Samson, 2007. The Network Service of Public. Published by Prentice Hall Ohio Press.

Josephina, Knoke, 2005. Alternatif of Public Service. London: Sage Publication.

Keban, Yeremis T, 2004. Indikator Kinerja Pemda: Pendekatan Manajemen dan Kebijakan. Yogyakarta (Makalah).

2005. Enam Dimensi Strategis Administrasi Publik: Konsep, Teori dan Isu. Jakarta: Gava Media.

Ketll, J.M, 2009, Organization Policy and Strategic Management. Hinsdale, III, Dryden Press.

Khasmir, 2007. Pelayanan Publik untuk Administrasi Pemerintahan. Jakarta: Grassindo. 
Khun, Hudson, 2006. Comparison of Administration Theories. Journal of Public Administration, Vol. 45 No. 4.

Klein, Gareth R, 2000, Organizational Administration Theory: Text and Cases. Addition Wesley Publishing Company, A \& M University, Texas.

Lewis, James. P, 2009. Public Policy: An Evolution Administration Approach. Belmont: Wadswort.

Listyadi, P, 2006. Pengantar Kebijakan Publik. (Penyunting Ricky Ismanto). Jakarta: PT. Raja Grafindo Persada.

Lukman, Sampara, 2009. Manajemen Kualitas Pelayanan. Jakarta: STIA-LAN Press.

Malay, Jorgy, 2009. The Structure of Unstructured Decision Processed. Prentice Hall, Ohio University.

Moore, Poppy, 2004. Organization Management. New York : Foresman and Company.

Muchlas, Zainal, 2009. Kebijakan Publik. Jakarta: Yayasan Pancur Siwah.

Mustopadijaja, 2007. Paradigmaparadigma Pembangunan Administrasi dan Manajemen Pembangunan.Makalah dibacakan pada Temu Kaji Posisi dan Ilmu Administrasi dan Manajemen Pembangunan Nasional. Diselenggarakan oleh LAN RI.
Namara, Crozier, 2010. The Administration Phenomenon. London: Tavistock.

Osborne et al, 2007. Implementation Theory and Practice : Tward a third generation, Glenview, Illinois, New York : Foresman and Company.

Pasolong, Harbani, 2007. Teori Administrasi Publik. Penerbit Alfabeta, Bandung.

Quinn, Robert E, 2005. A Competing Values Approach to Organization Effectivities. New York: Addison Wesley.

Rakhmat, Sartono, 2009. Memahami Good Governance dalam Kemitraan dengan Publik. Jakarta: PT. Grafindo Persada. 